\title{
INTENSI KEWIRAUSAHAAN SOSIAL MAHASISWA KOMUNIKASI SELAMA MASA PANDEMI COVID-19
}

\author{
Stepanus Bo'do \\ Jurusan Ilmu Komunikasi Fisip Universitas Tadulako \\ *Email: stepanusbodo@gmail.com
}

\begin{abstract}
This study aims to answer the question of why during the COVID-19 pandemic the interest in entrepreneurship among young Indonesians is very high. The research seeks to uncover entrepreneurial intentions with an analytical focus on the current dimensions of knowledge, personality, values, and entrepreneurial orientation. The survey was conducted online, attended by 153 students of Communication Science at Tadulako University. The results of the survey data analysis show that in line with efforts to incorporate entrepreneurship courses into the curriculum, entrepreneurial intentions among students are quite high. While the university curriculum is focused on preparing students to become professionals, the Covid-19 situation has encouraged students to contribute to overcoming social problems through social entrepreneurship.
\end{abstract}

Keywords: Entrepreneurship Intention; Social Entrepreneurship; Entrepreneur Character; Student Entrepreneur; Covid-19

\begin{abstract}
ABSTRAK
Penelitian ini bertujuan untuk menjawab pertanyaan mengapa di masa pandemi covid-19 minat wirausaha di kalangan anak-anak muda Indonesia sangat tinggi. Penelitian berupaya mengungkap intensi kewirausahaan dengan fokus analisis pada dimensi pengetahuan, kepribadian, nilai dan orientasi kewirausahaan saat ini. Survei dilakukan secara online, diikuti oleh 153 mahasiswa Komunikasi Fisip Universitas Tadulako. Hasil analisis data survey menunjukkan bahwa, sejalan dengan upaya memasukkan mata kuliah kewirausahaan ke dalam kurikulum, intensi kewirausahaan di kalangan mahasiswa cukup tinggi. Sementara kurikulum universitas difokuskan untuk menyiapkan mahasiswa menjadi tenaga profesional, situasi Covid-19 telah mendorong mahasiswa ikut berkontribusi mengatasi persoalan sosial melalui kewirausahaan sosial.

Kata Kunci: Intensi Kewirausahaan; Kewirausahaan Sosial; Karakter Pengusaha; Mahasiswa Pengusaha; Covid-19

Submisi: 15 November 2021

\section{Pendahuluan}

Secara global dampak negatif pandemi Covid-19 sangat besar. Tetapi di sisi lain, pandemik juga menawarkan peluang, termasuk bagi mahasiswa berkontribusi mengatasi krisis melalui kewirausahaan sosial. Sejumlah studi mengindikasikan adanya kecenderungan yang terus meningkat di kalangan muda di Indonesia Terjun ke dunia usaha dalam

beberapa tahun belakangan. Riset IDN Research Institute tahun 2019, menunjukkan $69,1 \%$ milenial di Indonesia memiliki minat berwirausaha. Data ini konsisten dengan rilis hasil survey tahunan World Economic Forum yang mengungkap lebih dari sepertiga anak muda Indonesia, antara usia 15 dan 35, ingin bekerja untuk diri mereka sendiri. Saat ini terdapat $34,1 \%$ anak muda di Indonesia telah bekerja untuk diri mereka
\end{abstract}




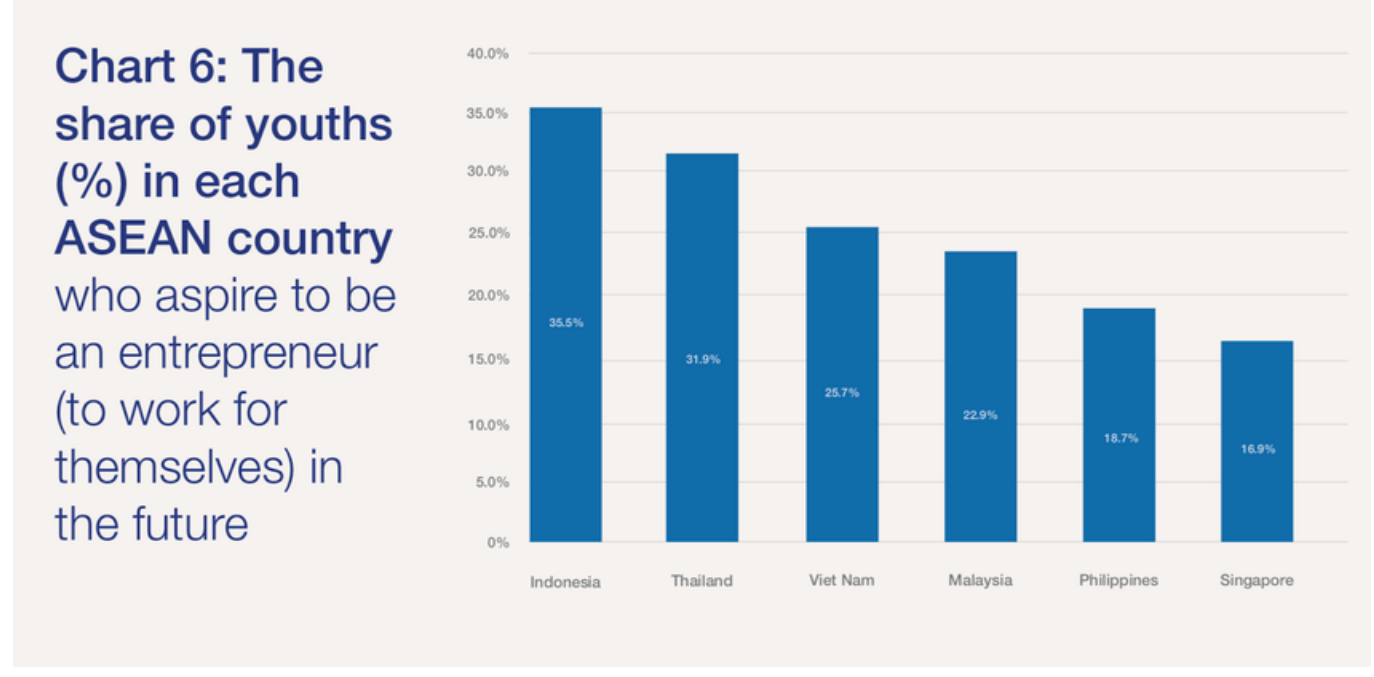

Gambar 1. Data Survey World Economic Forum

sendiri, dan 1,5\% lagi menginginkannya. Survei Forum Ekonomi Dunia tentang sikap kaum muda di negara-negara ASEAN mengungkapkan sebuah kawasan yang penuh dengan semangat kewirausahaan (In Indonesia, over a Third of Young People Want to Be Entrepreneurs, n.d.).

Figur pengusaha seperti Ferry Unardi (Traveloka), dan Nadiem Makarim (Gojek) yang masih berusia muda (30-an) telah membuktikan bahwa wirausahawan muda dapat mengubah perusahaan rintisan teknologi menjadi perusahaan bernilai triliunan rupiah dalam waktu relatif singkat. Munculnya anak-anak muda menciptakan sejumlah unicorn teknologi dari Indonesia, telah menginspirasi kaum muda. Sejak ditunjuk sebagai menteri pendidikan dalam kabinet Presiden Jokowi, Nadiem Makarim memasukkan kewirausahaan ke dalam kurikulum pengajaran di sekolah dan Universitas.

Dalam peringkat terbaru GEM NECI 2020, Indonesia berada di ranking pertama dengan point 6.4. Indeks Konteks Kewirausahaan Nasional Global Entrepreneurship Monitor (GEM NECI) bertujuan untuk memberi para pembuat kebijakan wawasan tentang cara mengembangkan lingkungan seperti itu. Indeks tersebut mengukur 12 kondisi lingkungan kewirausahaan (EFC) yang membentuk konteks di mana aktivitas kewirausahaan terjadi di suatu negara (GEM Staff, n.d.).

Data Pusat Statistik tahun 2020 mengungkapkan ditengah kondisi pandemi negara kita harus menanggung beban 7,05 juta pengangguran, termasuk pengangguran terdidik. Pemerintah berupaya menekan jumlah pengangguran, diantaranya melalui program peningkatan jumlah wirausahawan. Presiden Jokowi jauh-jauh hari telah menekankan tekat pemerintahannya untuk meningkatkan wirausaha. Ketika menerima audiensi Himpunan Pengusaha Muda Indonesia (Hipmi) di Istana Merdeka Jakarta (5/4/2018) Presiden Jokowi mengatakan, "negara kita membutuhkan entrepreneur yang tiap tahun meningkat. Angka entrepreneur di Indonesia saat ini baru sekitar 3,01 persen. Masih jauh dari angka ideal. Di negara maju standarnya kalau bikin entrepreneur itu sekitar 14 persen" (Himawan, 2018).

Pada tahun 2021 ini, pemerintah melalui Kemendikbud menyelenggarakan Kegiatan Berwirausaha Mahasiswa Indonesia (KBMI). Program ini untuk mendukung visi-misi pemerintah untuk pengembangan wirausaha baru dalam mewujudkan kemandirian bangsa melalui pengembangan kewirausahaan mahasiswa. Program ini diharapkan menghasilkan karya kreatif dan inovatif dalam membuka peluang usaha yang berguna bagi 
mahasiswa setelah menyelesaikan studi. Sebelumnya, Kemendikbud juga melaksanakan Program Kewirausahaan Kampus Merdeka memperkuat ekonomi nasional dan mendukung percepatan ekonomi digital menuju revolusi industri 4.0.

Berdasarkan rilis melalui Buku Panduan KBMI 2021, tahapan program ini akan meliputi sosialisasi, workshop, penerimaan usulan usaha, seleksi, penetapan penerima bantuan KBMI, pendampingan wirausaha, penilaian kemajuan pelaksanaan usaha dan Ekspo KMI sebagai puncak rangkaian kegiatan KBMI. Adapun tujuan KBMI 2021 adalah, menumbuhkan karakter wirausaha; menumbuhkembangkan wirausaha baru kreatif dan inovatif; membantu mahasiswa dalam menentukan keunikan usaha dengan menemukan celah pasar yang tepat untuk meningkatkan peluang keberhasilan usaha; dan mendukung implementasi kebijakan Merdeka Belajar Kampus Merdeka (MBKM).

Minat dan potensi wirausaha generasi milenial yang besar ini perlu didukung dan difasilitasi melalui tata kelola pendidikan tinggi yang mendukung program kewirausahaan mahasiswa di perguruan tinggi. Namun demikian, tampaknya program KBMI 2021 masih berfokus pada kewirausahaan tradisional, yang biasanya fokus terhadap keuntungan materi dan kepuasan pelanggan.Wirausaha sosial melihat masalah sebagai peluang untuk membentuk sebuah model bisnis baru yang fokus pada kemanfaatan kepada pemberdayaan masyarakat sekitar (Gregory Dees, 2001)

Saat ini social entrepreneurship menjadi fenomena sangat menarik saat ini karena signifikansinya terhadap kehidupan masyarakat. Kalangan mahasiswa cenderung sensitif terhadap permasalahan sosial di sekitarnya. Namun, masih sedikit studi mengenai sejauh mana intensi kalangan muda khususnya mahasiswa untuk terlibat dalam permasalah sosial melalui entrepreneurship. Oleh karena itu, studi berupaya mengungungkap sejauh mana pengetahuan mahasiswa dan intensinya untuk terjun ke bidang social entrepreneurship selama pandemi. Studi diharapkan memberi sumbangan sebagai bahan pertimbangan untuk merancang program serupa di kemudian hari.

\section{Tinjauan Pustaka}

Topik entrepreneurship di kalangan mahasiswa perguruan tinggi telah menjadi topik penelitian yang terus meningkat (Dan \& Popescu, 2018). Beberapa studi terbaru memasukkan faktor intensi entrepreneur sebagai faktor penting dalam peningkatan usaha sosial. Pandemic Covid-19 meningkatkan intensi entrepreneur di kalangan mahasiswa di Portugal (Lopes et al., 2021), pengetahuan dan intensi entrepreneur dipengaruhi oleh dukungan keluarga (Ikhram \& Novadjaja, 2020). Beberapa faktor pengaruh terhadap intensi kewirausahaan mahasiswa (Kamil, n.d.) dan (Sari et al., 2019). Dan secara khusus membahas faktor intensi sendiri di kalangan universitas swasta di Indonesia (Pradana \& Kartawinata, 2020) serta dalam konteks ekonomi kreatif ((Ramawati \& Sandroto, 2019).

Pilihan menjadi seorang entrepreneur seringkali dimulai dengan intensi yang kuat. Studi (Sieger et al., 2014) menunjukkan beberapa faktor pendukung intensi menjadi wirausaha. Studi (Jansen et al., 2015) mengungkapkan bagaimana edukasi, simulasi dan incubator sebagai menguatkan tekad mahasiswa ke wirausaha. Studi (Krichen \& Chaabouni, 2021) mengungkapkan Pandemi covid19 mengubah persepsi mahasiswa. Studi (Wang \& Huang, 2020) mengidentifikasi kebutuhan dukungan serta evaluasi terhadap faktor dukungan selama persiapan dan menjalan startup. Studi (Wu \& Mao, 2020) mengungkapan bahwa motivasi wirausaha mahasiswa secara positif dipengaruhi oleh persepsi mereka terhadap kondisi sosial 
ekonomi, edukasi, pelatihan, dan ketersediaan dukungan finansial. Studi ini secara spesifik menggambarkan seperti apa pengetahuan, karakteristik, konteks sosial ekonomi dan orientasi membentuk intensi kewirausahaan sosial di kalangan mahasiswa.

Meskipun konsep sosial entrepreneurship (kewirausahaan sosial) mungkin baru, tetapi inisiatif yang menggunakan kapasitas kewirausahaan untuk memecahkan masalah sosial tidaklah baru (Bidet \& Defourny, 2019) . Bahkan seiring meluasnya kesadaran bahwa semangat entrepreneurship di suatu wilayah menjadi salah satu kunci kemajuan, sosial entrepreneurship dipandang dapat menjadi mesin penggerak berikutnya bagi peradaban manusia dan mekanisme penting dari inovasi nilai bagi masyarakat (Chandra \& Wong, 2016). Telah muncul tuntutan bagi perusahaan dan organisasi nirlaba untuk memberikan solusi inovatif untuk mengelola masalah sosial yang kompleks: dari pengembangan masyarakat hingga pengucilan sosial serta pengurangan kemiskinan (Walsh et al., 2003).

Konsep kewirausahaan sosial dicetuskan oleh William (Bill) Drayton, pendiri dan CEO asosiasi internasional Ashoka, sebuah yayasan yang ada sejak 1980 mengidentifikasi, memilih, dan memberdayakan wirausahawan sosial dari hampir tujuh puluh negara. Menurut Drayton, wirausahawan sosial adalah individu dengan solusi inovatif untuk masalah sosial masyarakat yang paling mendesak (Praszkier \& Nowak, 2011).

Definisi kewirausahaan sosial menyiratkan bahwa wirausahawan sosial muncul dengan ide-ide baru untuk memecahkan masalah sosial yang mendesak. Mereka kreatif dan memiliki tujuan, bertekad menyebarkan ide-idenya di luar lingkaran terdekat mereka; terlebih lagi, biasanya mereka sangat etis (Perrini \& Vurro, 2006). Di China misalnya, kewirausahaan sosial telah mengambil ide dan pola pikir "Wangdao", yang mengandung tiga nilai inti: penciptaan nilai, keseimbangan kepentingan, dan pembangunan berkelanjutan.

\section{Konseptualisasi Penelitian}

Dalam kamus Merriam-Webster istilah intention merujuk pada pengertian the thing that you plan to do or achieve : an aim or purpose. Dalam kamus Oxford Dictionaries istilah intention merujuk pada thing intended; an aim or plan. Dengan demikian dapat dikatakan bahwa Intensi adalah" who you want to Be", Anda mau jadi Siapa. Dalam konteks penelitian ini, intensi social entrepreneurship dimaksudkan adalah perencanaan yang disertai komitmen untuk menjadi seorang social entrepreneur.

Dalam literatur tentang kewirausahaan, beberapa model dan teori dapat ditemukan yang membantu untuk memahami intensi kewirausahaan (Lopes et al., 2021). Diantaranya model implementing entrepreneurial ideas (IEI) oleh (Bird, 1988). Dalam model Bird, niat entrepreneur dimulai sebagai respons terhadap interaksi antara faktor pribadi dan kontekstual. Faktor pribadi seperti pengetahuan sebelumnya, karakteristik dan kapasitas kepribadian. Adapun faktor kontekstual mencakup variabel sosial, politik dan ekonomi. Penelitian ini meminjam model IEI ini sebagai kerangka kerja untuk menganalisis intensi kewirausahaan mahasiswa dengan mempertimbangkan faktor karakteristik dan kapasitas pribadi serta ekosistem sosial, ekonomi politik.

Penelitian ini dilaksanakan dalam upaya memetakan pengetahuan dan intensi kewirausahaan mahasiswa. Penelitian menggunakan kuesioner atau survey online 
Jenis Kelamin

150 jawaban

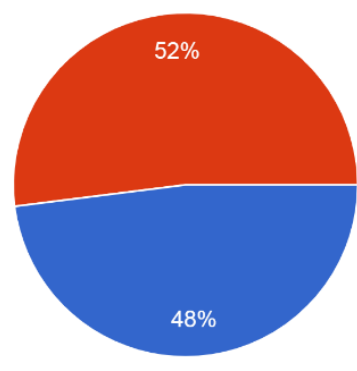

Laki-Laki

Perempuan

Dari mana kamu mengetahui istilah kewirausahaan social/social entrepreneurship

151 jawaban
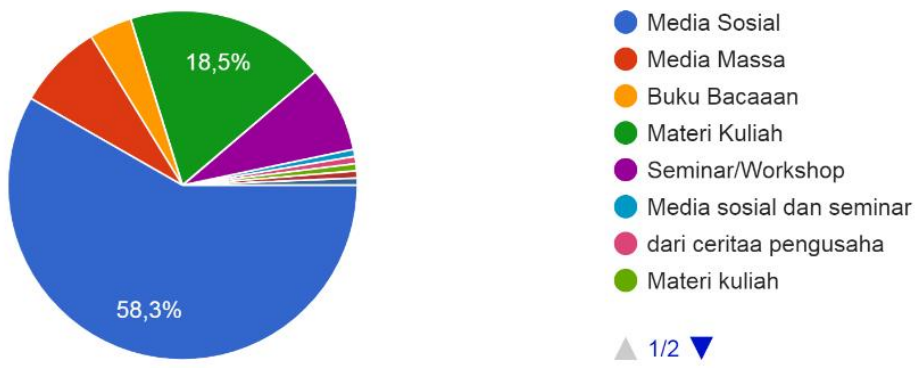

Gambar 2. Grafik data responden

pada periode September 2021. Kuesioner disebar secara terbatas pada peserta Mata Kuliah Kewirausahaan melalui whatsapp group dan Google Classroom. Survey secara online memakai aplikasi Google Form di alamat forms.google.com. Pertanyaan yang diajukan dikombinasi antara pertanyaan terbuka dan tertutup. Responden dapat mereview kembali isiannya dengan membuka fitur review respons. Responden adalah mahasiswa komunikasi yang sedang mengikuti Mata Kuliah Kewirausahaan. Terdapat 153 responden yang berpartisipasi dalam survey ini. Penting dicatat bahwa survey online mengandalkan ingatan, yang seringkali tidak sempurna. Temuan tidak boleh dianggap sebagai perwakilan keseluruhan mahasiswa Komunikasi Fisip Untad.

\section{Hasil Penelitian \\ Pengetahuan Responden}

Sebanyak 153 responden mengisi online survey yang dikirim melalui group
Whatsapp dan aplikasi Google Classroom. Ada 150 responden mengisi data jenis kelamin, dimana $52 \%$ adalah perempuan dan $48 \%$ laki-laki. Ada tiga pertanyaan tertutup ditanyakan untuk mengetahui secara umum informasi dan pengetahuan tentang kewirausahaan dan konsep social entrepreneurship yang diketahui responden. Masih ada sekitar 8\% responden yang mengaku tidak tahu konsep kewirausahaan dan $285 \%$ masih ragu-ragu. Yang mengaku tahu sebanyak 62,9\%. Angkanya hampir sama pada pengetahuan tentang social entrepreneurship. Sebanyak 51,7\% mengaku tahu, $35 \%$ ragu-ragu dan $12,8 \%$ tidak tahu. Adapun sumber informasi mengenai konsep social entrepreneurship responden menempatkan sosial media di urutan teratas yakni sekitar 58,3\% menyusul materi kuliah 18,5\% dan seminar/workshop $7,9 \%$. Untuk pertanyaan apakah fokus 
Apakah kamu berpikir memiliki sifat/karakter pengusaha

150 jawaban

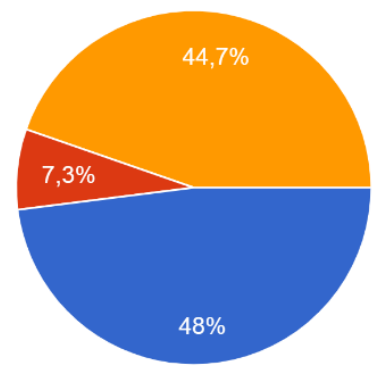

Kalau Ya, manakah karakter berikut yang kami miliki

134 jawaban

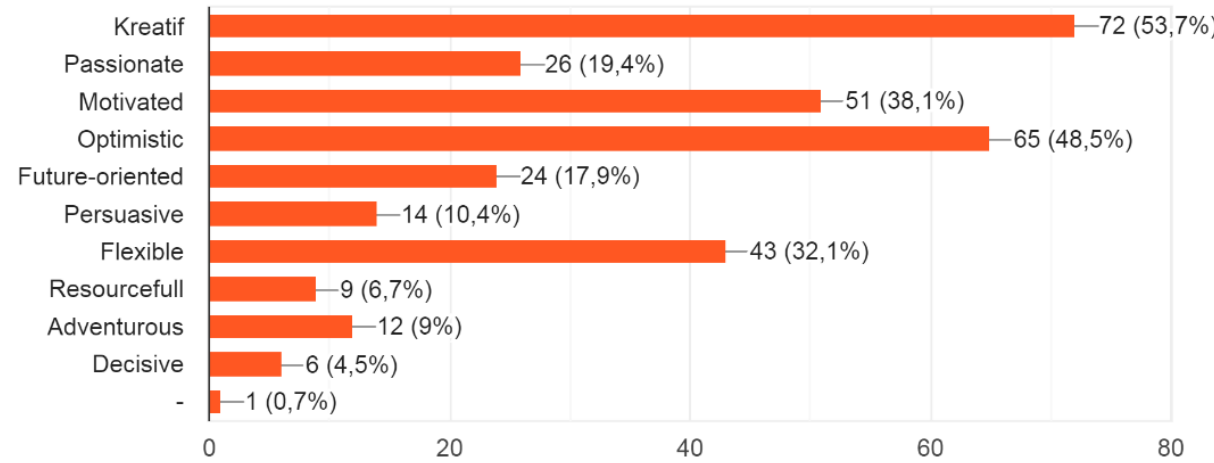

Gambar 2. Grafik data sifat/karakter

utama kewirausahaan sosial yang mereka ketahui, 47,7\% responden memilih "keuntungan". Adapun "manfaat sosial" dipilih 40,4\% responden dan "kontribusi sosial" ( $31,8 \%)$.

\section{Kepribadian Pengusaha}

Untuk menilai persepsi tentang kepribadian pengusaha, responden diminta memilih mana karakter entrepreneur yang utama. Terdapat $77,3 \%$ responden memilih karakter kreatif. Menyusul karakter optimistik 58,7\% dan motivated 36,7\%. Adapun karakter manipulatif dipilih sebagai karakter buruk pengusaha, dipilih oleh $54 \%$ responden. Karakter hanya mencari untung dipilih oleh $50 \%$ responden, menyusul sifat pelit $(24,7 \%)$ dan licik $(45,3)$. Responden dapat memilih lebih dari satu opsi yang ditawarkan dalam kuesioner. Terhadap pertanyaan apakah memiliki karakter entrepreneur, hanya 7,3\% mengaku tidak memiliki dan $48 \%$ mengaku memiliki karakter entrepreneur.

\section{Kontek sosial,politik, ekonomi}

Persepsi mengenai ekosistem bisnis erat kaitannya dengan dukungan dan kendala yang ada. Kepada responden ditanyakan masalah-masalah mana saja yang mereka pikir menjadi kendala memulai bisnis. Sebanyak 70,6\% responden memilih masalah tidak adanya modal usaha, menyusul kurangnya keterampilan manajemen usaha $(36,4 \%)$ dan kurangnya keterampilan teknis (32,9\%). Namun, pengalaman bermitra dan bertransaksi online di marketplace maupun kesempatan bermitra dengan dengan aplikasi bisnis cukup umum untuk responden.Sebanyak 49,2\% responden mengaku sudah memakai 
Aplikasi Gojek, menyusul Grab (26,7\%) dan Maxim (17,5\%).
Yang masih ragu $(47,3 \%)$ dan $6,8 \%$ mengatakan Tidak. Adapun orientasi utama

Masalah-masalah mana yang menjadi hambatan kamu memulai bisnis 143 jawaban

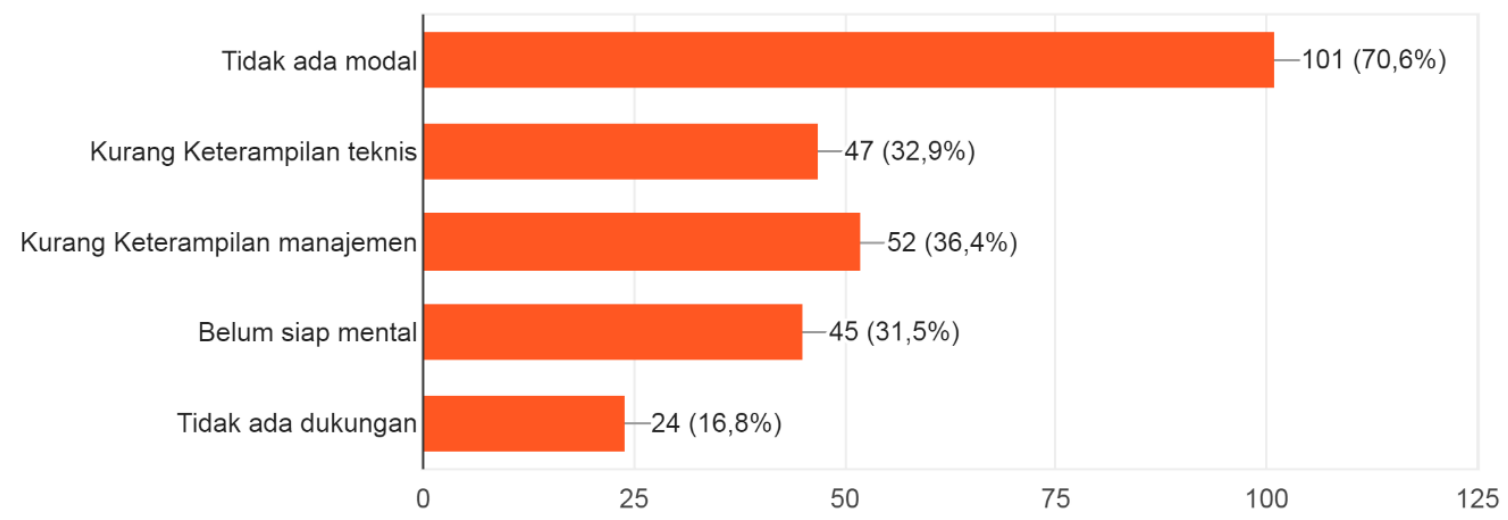

Manakah layanan ojek online berikut yang paling sering kamu pakai 120 jawaban
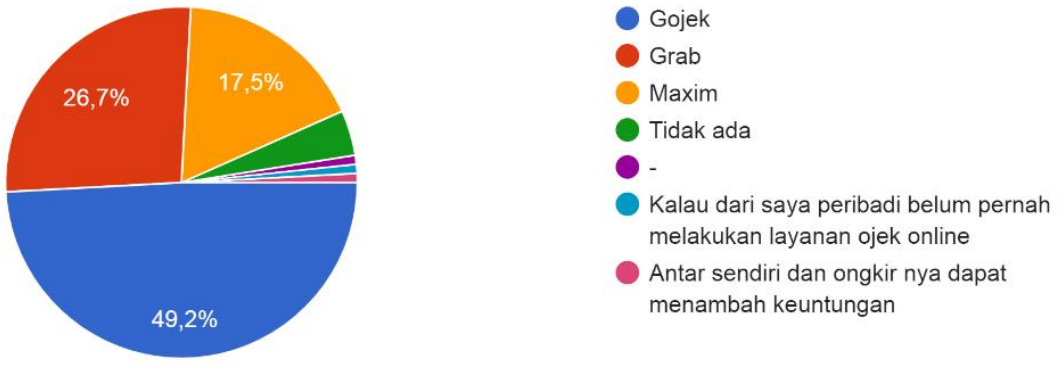

Jika nanti membuka usaha, manakah yang akan menjadi orientasi utama kamu 145 jawaban

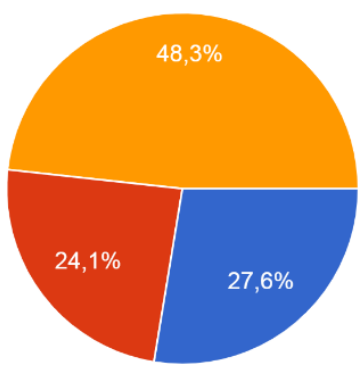

Profit

Kontribusi Sosial

Pengembangan diri

Gambar 3. Grafik data hambatan, layanan dan orientasi kewirausahaan

\section{Orientasi Kewirausahaan}

Untuk pertanyaan apakah masa kuliah adalah waktu terbaik memulai bisnis sekarang, 54,9\% responden mengatakan Ya. kewirausahaan saat ini adalah pengembangan diri $(48,3 \%)$ profit $(27,6 \%)$ dan, kontribusi sosial $(24,1)$. 


\section{Analisis dan Interpretasi}

Argumen utama penelitian ini adalah bahwa intensi kewirausahaan dipengaruhi oleh faktor karakteristik personal dan konteks sosial, budaya, ekonomi, dan politik. Karena itu, kuesioner didesain untuk mengetahui pengetahuan, karakter dan konteks sosial ekonomi mahasiswa serta intensi kewirausahaan sekarang ini. Sebagaimana ditunjukkan dalam sejumlah hasil riset terakhir, minat kewirausahaan khususnya di kalangan muda di Indonesia dan Asia pada umumnya mengalami peningkatan (Tambunan, 2020; OVERVIEW OF MSMEs IN INDONESIA AND MALAYSIA, 2018).

Akses terhadap sosial media, ketersediaan materi kuliah dan akses terhadap seminar atau workshop kewirausahaan secara daring selama pandemik meningkatkan pengetahuan mahasiswa. Data survey menunjukkan bahwa mayoritas responden mengaku mendapatkan informasi mengenai kewirausahaan melalui sosial media. Bukan saja pada konsep kewirausahaan tetapi juga kewirausahaan sosial. Kecenderungan figurfigur pengusaha terkemuka global seperti Elon Musk (SpaceX) atau Jeff Bezos (Amazon) atau pengusaha nasional yang diidolakan seperti Achmad Zaky(Bukalapak), Susi Pudjiastuti (Susi Air) membagikan aktivitas mereka ke media sosial memperkuat image tentang menjadi seorang entrepreneur. Hal ini juga memungkinkan kalangan muda mengenali karakter kepribadian khas dalam diri mereka, seperti daya inovasi dan kreativitas tinggi, fleksibel, serba bisa dan memiliki jaringan bisnis yang luas. Secara umum karakter entrepreneur mencakup percaya diri, berorientasikan tugas dan hasil, pengambil risiko, kepemimpinan, berorientasi ke masa depan, jujur dan tekun (Rissal, 1988). Namun, sebagaimana terungkap dari hasil survey, ciri entrepreneur juga dikaitkan dengan sifat negatif seperti hanya mencari untung, pelit dan licik.
Menghadapi krisis sosial pandemi covid-19, pemerintah Indonesia melakukan berbagai langkah strategis. Pada tahun 2021, pemerintah melalui Direktorat Pembelajaran dan Kemahasiswaan, Direktorat Jenderal Pendidikan Tinggi, Kementerian Pendidikan dan Kebudayaan (Kemdikbud) menyelenggarakan Kegiatan Berwirausaha Mahasiswa Indonesia (KBMI) tahun 2021. Upaya ini diharapkan menciptakan kondisi lingkungan yang optimal bagi individu untuk memulai dan mengembangkan bisnis. Sebelumnya, Kemendikbud telah memasukkan Kewirausahaan sebagai mata kuliah wajib bagi mahasiswa di Perguruan Tinggi untuk mendukung implementasi kebijakan Merdeka Belajar Kampus Merdeka (MBKM). Akses terhadap materi kewirausahaan dalam kurikulum menunjang pengetahuan dan minat kewirausahaan di kalangan responden.

Survey ini mengindikasikan bahwa ada peningkatan minat responden untuk intensi wirausaha yang berkontribusi sosial, mengatasi persoalan sosial yang nyata di lingkungannya. Meskipun mayoritas mengatakan wirausaha sosial tetap menghasilkan keuntungan, tetapi sekaligus juga berkontribusi sosial dan pengembangan kapasitas individu. Pengalaman pandemik telah memunculkan kesadaran di kalangan mahasiswa untuk ikut berkontribusi positif mengatasi krisis yang terjadi.

Secara global, wabah COVID-19 mempengaruhi semua segmen populasi dan sangat merugikan anggota kelompok sosial tersebut dalam situasi yang paling rentan, seperti kelompok masyarakat miskin, manula, penyandang disabilitas, pemuda, dan suku-suku asli. Lembaga PBB telah mencatat bukti awal yang menunjukkan bahwa dampak kesehatan dan ekonomi dari virus ini ditanggung secara tidak proporsional. Jika tidak ditangani dengan baik melalui kebijakan, krisis sosial yang diakibatkan oleh pandemi COVID-19 dapat meningkatkan ketimpangan, eksklusi, 
diskriminasi, dan pengangguran global dalam jangka menengah dan panjang.

Secara keseluruhan, pandemi COVID-19 membutuhkan solusi global dan solidaritas antargenerasi, dan untuk solusi kebijakan yang inovatif dan inklusif. Para ahli PBB mengusulkan agar orang-orang muda dilibatkan mendukung respon kesehatan masyarakat dengan mengambil tanggung jawab. Permasalahan sosial yang kompleks dan saling tumpang tindih selama pandemi tidak cukup diselesaikan hanya dengan konsep kewirausahaan dan nilai tambah saja. Masalah ketimpangan, eksklusi, diskriminasi, dan pengangguran global hanya dapat diselesaikan dengan menekankan nilai-nilai sosial yang dikawinkan dengan nilai-nilai entrepreneurship. Berdasarkan pengalaman, krisis sosial dapat diatasi melalui inovasi kewirausahaan sosial yang muncul dari kelompok terdampak (Rüdiger et al., 2013), (De Simone et al., 2021).

$\begin{array}{ccc}\text { Jauh } & \text { sebelum pandemik, minat } \\ \text { terhadap } & \text { social } & \text { entrepreneurship }\end{array}$ berkembang pesat dan menarik perhatian banyak orang karena diyakini menjadi mesin penggerak berikutnya bagi peradaban manusia dan mekanisme penting dari inovasi nilai bagi masyarakat. Praktik social entrepreneur yang dilakukan oleh Muhammad Yunus melaleuca Green Bank di Bangladesh telah memicu minat secara global terhadap upaya seru apa. Muhammad Yunus mendapat hadiah nobel pada 1989 karena upaya kewirausahaan sosial. Social entrepreneurship muncul dengan memadukan usaha bisnis dengan nilai-nilai sosial yang kental di dalamnya (Beck, 2011; Martin \& Osberg, 2015; Mills, 2016).

\section{Simpulan}

$\begin{array}{rrr} & \text { Perguruan tinggi memiliki peran } \\ \text { penting untuk mendorong dan }\end{array}$ meningkatkan jumlah wirausaha muda di Indonesia. Lulusan perguruan tinggi itu harus disiapkan untuk berkontribusi serta berperan untuk ikut membangun perekonomian bangsa.

Pandemi Covid-19 telah memunculkan persoalan sosial ekonomi yang kompleks yang harus dihadapi institusi maupun individu. Tantangan menemukan solusi yang efektif dan berkelanjutan untuk banyak masalah sosial tersebut menjadi tugas semua orang saat ini. Solusi untuk masalah sosial seringkali menuntut transformasi mental dalam sistem politik, ekonomi, dan sosial.

Intensi kewirausahaan di kalangan mahasiswa Ilmu Komunikasi Untad cukup tinggi di tengah krisis pandemik covid-19. Hal ini sejalan dengan kewirausahaan sosial dipandang sebagai mesin penggerak baru peradaban manusia dan mekanisme penting dari inovasi nilai bagi masyarakat. Kedepan, diperlukan studi lebih lanjut bagaimana intensi kewirausahaan mahasiswa mengarah kepada keputusan menginisiasi perusahaan rintisan yang inovatif dan bertujuan kontribusi sosial.

\section{Referensi}

Beck, M. (2011). Social Business as a Sustainable Business Concept: Developed by Muhammad Yunus and the Grameen Bank. GRIN Verlag.

Bidet, E., \& Defourny, J. (2019). Social Enterprise in Asia: Theory, Models and Practice. Routledge.

Bird, B. (1988). Implementing Entrepreneurial Ideas: The Case for Intention. In Academy of Management Review (Vol. 13, Issue 3, pp. 442-453). https://doi.org/10.5465/amr.1988.43 06970

Chandra, Y., \& Wong, L. (2016). Social Entrepreneurship in the Greater China Region: Policy and Cases. Routledge.

Dan, M. C., \& Popescu, A. I. (2018). ENTREPRENEURSHIP EDUCATION IN ROMANIAN UNIVERSITIES: DEVELOPING 
STUDENT ENTREPRENEURIAL BEHAVIOUR. In EDULEARN18 Proceedings.

https://doi.org/10.21125/edulearn.20 18.2464

De Simone, S., Pileri, J., Rapp-Ricciardi, M., \& Barbieri, B. (2021). Gender and Entrepreneurship in Pandemic Time: What Demands and What Resources? An Exploratory Study. Frontiers in Psychology, 12, 668875.

GEM Staff. (n.d.). Global Entrepreneurship Monitor Releases Ranking of Countries for Conditions to Start a Business. Retrieved November 7, 2021, from https://www.gemconsortium.org/ne ws/global-entrepreneurshipmonitor-releases-ranking-ofcountries-for-conditions-to-start-abusiness

Gregory Dees, J. (2001). The Meaning of Social Entrepreneurship.

Himawan, A. (2018, April 5). Jokowi: Jumlah Entrepreneur di Indonesia Baru 3,01 Persen. Suara.com. https://www.suara.com/bisnis/2018/ 04/05/152916/jokowi-jumlahentrepreneur-di-indonesia-baru-301persen

Ikhram, A. D., \& Novadjaja, L. H. (2020). The Effect of Entrepreneurial Knowledge on Entrepreneurial Intention with the Moderation of Family Support (A Case Study on University Students in Indonesia). In Asia Pacific Management and Business Application (Vol. 008, Issue 03, pp. 169-180). https://doi.org/10.21776/ub.apmba.2 020.008.03.2

In Indonesia, over a third of young people want to be entrepreneurs. (n.d.). Retrieved November 14, 2021, from https://www.weforum.org/agenda/2 019/08/indonesia-young-peopleentrepreneur/

Jansen, S., van de Zande, T., Brinkkemper, S., Stam, E., \& Varma, V. (2015). How education, stimulation, and incubation encourage student entrepreneurship: Observations from MIT, IIIT, and Utrecht University. The International Journal of Management Education, 13(2), 170181.

Kamil, A. (n.d.). Factors Affecting on Entrepreneurial Intention of University Students (Case Study on Wollo University). https://doi.org/10.21203/rs.3.rs736445/v1

Lopes, J. M., Gomes, S., Santos, T., Oliveira, M., \& Oliveira, J. (2021). Entrepreneurial Intention before and during COVID-19-A Case Study on Portuguese University Students. In Education Sciences (Vol. 11, Issue $6, \quad$ p. 273). https://doi.org/10.3390/educsci1106 0273

Martin, R. L., \& Osberg, S. (2015). Getting Beyond Better: How Social Entrepreneurship Works. Harvard Business Review Press.

Mills, C. (2016). "Building Social Business" by Muhammad Yunus. An Essay. GRIN Verlag.

OVERVIEW OF MSMES IN INDONESIA AND MALAYSIA. (2018). In Accidental and Intentional Exporters (pp. 4-28). https://doi.org/10.1355/9789814818 322-003

Perrini, F., \& Vurro, C. (2006). Social Entrepreneurship: Innovation and Social Change Across Theory and Practice. In Social Entrepreneurship (pp. 57-85). https://doi.org/10.1057/9780230625 655_5

Pradana, M., \& Kartawinata, B. R. (2020). Indonesian Private University Students' Entrepreneurial Intention. In Asia Pacific Management and Business Application (Vol. 009, Issue 02, pp. 111-122). https://doi.org/10.21776/ub.apmba.2 020.009.02.3

Praszkier, R., \& Nowak, A. (2011). Social 
Entrepreneurship: Theory and Practice. Cambridge University Press.

Ramawati, Y., \& Sandroto, C. W. (2019). Entrepreneurial Intention: A Case of Entrepreneurs in Creative Economy. In Proceedings of the 2nd International Conference on Inclusive Business in the Changing World. https://doi.org/10.5220/0008430803 190328

Rissal, R. (1988). A Study of the Characteristics of Entrepreneurs in Indonesia.

Rüdiger, K., Ortiz, M. P., \& González, A. B. (2013). Entrepreneurship, Innovation and Economic Crisis: Lessons for Research, Policy and Practice. Springer Science \& Business Media.

Sari, M. R., Munandar, J. M., Cahyadi, E. R., Borowy, M., \& Adha, I. M. (2019). Determinants of Entrepreneurial Intention among University Students: A Comparative Study between IPB University (Indonesia) and WULSS-SGGW (Poland). In Proceedings of the 2nd Economics and Business International Conference. https://doi.org/10.5220/0009204603 600368

Sieger, P., Fueglistaller, U., \& Zellweger, T. (2014). Student Entrepreneurship Across the Globe: A Look at Intentions and Activities. https://www.alexandria.unisg.ch/23 1545

Tambunan, T. (2020). MSMEs IN TIMES OF CRISIS. EVIDENCE FROM INDONESIA. In Journal of Developing Economies (Vol. 5, Issue 2 , p. 91). https://doi.org/10.20473/jde.v5i2.20 848
Walsh, J. P., Weber, K., \& Margolis, J. D. (2003). Social Issues and Management: Our Lost Cause Found. In Journal of Management (Vol. 29, Issue 6, pp. 859-881). https://doi.org/10.1016/s01492063_03_00082-5

Wang, P., \& Huang, Y. (2020). Give Me What I Want: Identifying the Support Needs of College Student Entrepreneurs. Frontiers in Psychology, 11, 1428.

Wu, F., \& Mao, C. (2020). Business Environment and Entrepreneurial Motivations of Urban Students. Frontiers in Psychology, 11, 1483. 